\title{
INTOLERABLE IDEOLOGIES AND THE OBLIGATION TO DISCRIMINATE
}

\section{ABSTRACT}

In this paper, I argue that businesses bear a pro tanto, negative, moral obligation to refuse to engage in economic relationships with representatives of intolerable ideologies. For example, restaurants should refuse to serve those displaying Nazi symbols. The crux of this argument is the claim that normal economic activity is not a morally neutral activity but rather an exercise of political power. When a business refuses to engage with someone because of their membership in some group, e.g., Black Americans, this is a use of political power to signal that Black Americans are other. Conversely, when businesses engage with someone who is clearly representing an intolerable ideology, this is a use of political power that signals the acceptability of that ideology. Businesses should not do this.

\section{INTRODUCTION}

In the summer of 2017, a "Unite the Right" rally was held in Charlottesville, Virginia. The stated purpose of the rally was to oppose the removal of a Confederate memorial from a public park, but the participants in this rally were not just conservatives, history buffs, and proud Southerners. Among their number were white nationalists, white supremacists, members of the Ku Klux Klan, and neo-Nazis. ${ }^{1}$ The rally drew counter-protesters, the atmosphere was tense, and blood was spilled. One counter-protester, Heather Heyer, was killed by a marcher.

Like many business owners in Charlottesville, Brian Ashworth shuttered his shop on the day of the rally, wishing to avoid any of the ugly confrontations that might occur between his regular patrons, or himself, and the marchers. However, he opened his restaurant the following day, thinking that the

1 I will use the term 'Nazi' in its colloquial sense throughout the paper, making no claims about the formal political affiliations of those to whom the term is being applied. 
conflict had passed. When a group entered the restaurant wearing shirts clearly indicating their sympathy with, if not participation in, the Unite the Right rally, Ashworth served them contrary to his preferences. The customers weren't doing anything overtly offensive, though one wore a shirt for a prominent white supremacist band, Skrewdriver. After dining, the group did not immediately leave, but remained to chat and smoke. As other local patrons began arriving, the group began making Nazi salutes. At this point, Ashworth demanded that they leave. Their response was, predictably, uncooperative and threatening.

Encounters like this and other recent political developments make the following question pressing: what obligations does a business have when it comes to engaging with representatives of hateful, repugnant ideologies? Was Ashworth morally justified in ejecting the neo-Nazis from his establishment? Would he have been morally justified if he let them stay?

I argue not just that Ashworth's actions were justified, but that he had a moral obligation to act as he did once the neo-Nazis made their commitment to an ideology of genocide clear. More generally, I argue that all businesses ${ }^{2}$ have a moral obligation to refuse to engage in business relationships with representatives of genocidal ideologies, or any other ideologies that are intolerable in a liberal society.

This fairly robust conclusion can be supported by relatively weak premises. Even if you think that we have no obligation to limit the activities of Nazis, few would argue that it is morally acceptable to aid Nazis in spreading their ideology. However, businesses do just this when they treat an obvious Nazi as just another customer. They may not intend to do so, but engaging with Nazis in quotidian market transactions normalizes both their presence in society and their ideology, weakening our justified repugnance toward them, and, ultimately, contributing to the inclusion of their ideology among those jostling for position in our political discourse. No one should act in a manner that helps to bring about that outcome.

2 Or the agents thereof. I don't think I need to take a stance here concerning the agency of organizations. 
My aim in this paper is to establish that normal business activity is not a socio-politically neutral or purely private activity. It is too much a part of the fabric of our lives for that. Because of the centrality and indispensability of business activity, there is no middle position between demonstrating disapproval of a representative of a group and lending social acceptability to that representative, and thus to the group represented. Because there is no middle ground to occupy and it is morally unacceptable to contribute to the inclusion of genocidal ideologies in public discourse, businesses have a negative moral obligation to refuse to do business with representatives of such ideologies. They might also have a positive moral obligation to do so, but I will not argue for that claim here. In this way, I hope that the premises of this argument will be acceptable even to those who have a minimalist view of the moral responsibilities of businesses.

The outline of my argument is as follows:

(P1) There is a negative, pro tanto, moral obligation to not exercise political power in such a way that it contributes to the inclusion of intolerable ideologies in public discourse

(P2) Increased social acceptance of representatives of an ideology or practice contributes to the inclusion of that ideology or practice in public discourse

(C1) There is a negative, pro tanto, moral obligation to not exercise political power in such a way that it grants social acceptance to representatives of intolerable ideologies (from P1, P2)

(P3) Entering into business relationships with a representative of an ideology (i) is an exercise of political power that (ii) grants social acceptance to that representative

(C2) There is a negative, pro tanto, moral obligation to not enter into business relationships with representatives of intolerable ideologies (from C1, P3)

\section{$\S 1$ THE ARGUMENT}

\section{(P1) There is a negative, pro tanto, moral obligation to not exercise political power in such a way that it contributes to the inclusion of intolerable ideologies in public discourse}

In a liberal society, the ideal is for all proposals to enter into the realm of public discourse, wherein they are vigorously debated and accepted or rejected on their merits. It is naive, however, to think that we are capable, flawed and twisted timber that we are, of reaching this ideal. In attempting to do so, we must 
take account of our shortcomings or risk serious, perhaps catastrophic, harm. Some ideas are dangerous, and our capacity for pure, rational evaluation of ideas is limited. We accept some ideas out of fear, some out of love, some out of exhaustion, and some out of bias or pique. Some of us are ambivalent, indifferent, or outright hostile toward rational discourse. Thus, it is necessary and appropriate in a liberal society for some ideas to be kept out of the public sphere.

Still, as Mill (1859) cautions, we must be careful that we do not infantilize ourselves or our fellows, and in the process constrain both the growth that can occur from consideration of new and strange inclusions in the marketplace of ideas and the liberty of those who represent them. Striking a balance between liberty and safety is notoriously difficult. For those working in the field of liberal political philosophy, determining just what an open society must tolerate and what it must not is a fraught question. Some maintain that a liberal society must not tolerate views that threaten the existence or liberty of the society itself (Popper 1945: n4, ch7 and Rawls 1971: 220 and 2005: 58-62), others that they must not tolerate views that present a clear and present threat of harm (Mill 1859). Still others maintain that no views are intolerable because the institutions of a liberal society are strong enough to win out against any view. ${ }^{3}$

Owing to the various ways in which humans, individually or collectively, fail to adhere to the ideals of rational discourse, this last view, at least, is mistaken. Consider, for example, the backfire effect: when faced with evidence contrary to our deeply held political views, we tend to increase rather than decrease our credence in those views (Nyhan and Reifler 2010). If we hope that the light of truth will guide all away from views predicated on false assumptions, we will be sorely disappointed.

Furthermore, discourse is, for some, an exercise in bad faith. For example, some gun rights activists who claim in anti-gun violence forums that they merely wish to have a frank exchange of ideas actually desire no such thing; instead, they use the request for dialogue as a tool of manipulation. If anti-

3 Thomas Jefferson might be read as suggesting something like this in his first inaugural address to Congress, although it seems pretty clear that he means that the government should tolerate all views, not that society should tolerate all views. 
gun violence activists engage with them, they quarrel ad nauseum, requesting data that is not available, and claim victory when the anti-gun activists end the conversation in frustration. If, on the other hand, anti-gun violence activists refuse to engage them in dialogue, they can claim that the anti-gun violence movement is unreasonable and illiberal.

For these reasons, we must accept that a commitment to rational discourse is not a commitment to give equal hearing to all ideas and all speakers. The primacy of rational discourse is a regulative ideal; accepting this is consistent with taking some propositions to be beyond the pale. If an adult unknown to you comes to your home and asks for the opportunity to spend an unsupervised evening with your child, you are in violation of no norms of the liberal society when you close the door in their face without debate. The proposition was obviously and fundamentally unacceptable.

But what are the necessary and sufficient conditions for inclusion among intolerable ideologies? Part of the impetus for this paper was an observed aversion to public debate on the delimitation of the unacceptable. This debate would be substantive, taking us beyond the purely formal debates with which we are more comfortable. ${ }^{4}$ To carry out what I call for in this paper, businesses would have to take a stance on this issue and should be amenable to emendation. ${ }^{5} \mathrm{I}$ believe that there is an objective fact of the matter about which ideologies are intolerable, and the public debate would be an attempt to discover that fact. However, I am open to the possibility that it is a social construction, and the debate is an attempt at that construction. ${ }^{6}$ Either way, the debate is necessary. ${ }^{7}$

4 See Michael Sandel (1996) for a defense of the claim that substantive debate concerning moral categories is the tonic necessary to address various impasses at which we in the U.S. have arrived.

5 For those worried that this approach would permit businesses to discriminate against any groups whatsoever, I take up this issue in section 3 below.

6 Within limits. The fact that everyone within a nation supports genocidal ideologies would do nothing to make those ideologies anything more than intolerable. Just how to develop a constructivist ethical framework is obviously beyond the scope of this paper.

7 How to have a debate about which ideologies are intolerable without thereby lending social cache to those ideologies is a vexed question. I will not address it here except to say that there is the public sphere and then there is the subset of the public sphere that are equipped to have this conversation. I do not care to weigh in on just who falls within the second category. 
But to defend a particular stance in that debate is well beyond the scope of this paper. For current purposes, I would like to take for granted that some ideologies ought to be barred from public discourse in a liberal society, that some views, in virtue of their content or consequences, should be dismissed without public hearing. I use ideologies that call for genocide as my toy example, but I assume there are others that deserve no public hearing, that deserve only extirpation. Such views are intolerable in a liberal society.

Even if the issue of which views are intolerable were settled, a further point of contention might arise concerning what it takes for a given belief to belong to a given ideology. It must be admitted that ideologies are vague and fluid, dividing, subdividing, and merging often. An account of the delimitation of ideological movements strikes me as the work of sociology or social psychology and, therefore, outside of my area of expertise. For the sake of this argument, it will suffice to focus on those views that obviously cannot be divorced from their intolerable features, while acknowledging that determining which ideologies have intolerable features will often be difficult and uncertain. ${ }^{8}$

My own views on this issue are quite strong. I believe that all citizens, private or public, have a strong, positive, moral obligation to bar intolerable ideologies from the public sphere. The present argument, however, relaxes this position in three ways. First, the obligation need only apply to the use of political power. Nothing I defend in this paper would indicate that it is wrong to have a personal relationship with a Nazi. Second, the obligation need only be negative; it is an obligation to merely avoid doing something. Third, the obligation need only be pro tanto, i.e., it need only be a consideration in favor of an option, one that might be outweighed by other considerations.

The resulting position is that there is a moral consideration against exercising political power in such a way that it contributes to the acceptance of intolerable ideologies into the public discourse. This position is consistent with the view that private citizens are under no obligation to crusade against, or

8 Thank you to an anonymous referee for pushing me on this point. 
even avoid, white supremacists, though it may well imply that they have an obligation to avoid voting for them or their champions. ${ }^{9}$

\section{(P2) Increased social acceptance of representatives of an ideology or practice contributes to the inclusion of that ideology or practice in public discourse}

The extent to which someone is socially accepted is the extent to which their voice is a part of the public discourse. Social acceptance entails accepting that someone is a member of the community, which means that their concerns are relevant, that they must be taken seriously even if they are ultimately dismissed. This is all it takes for views to be included in public discourse. Note that a view does not have to be politically viable to be a part of public discourse; it merely needs to be treated as a live option for that society by a significant number of people within that community, even if only a very small portion of that community supports the view.

It is entirely possible to accept an individual who happens to be a representative of an ideology into the community and still exclude the ideology represented. Insofar as the individual is not considered a representative of that ideology, or that representation is ignored, they are not socially accepted qua representative. Consider, for example, the term "one of the good ones," used as a way to distinguish between concern for individuals who happen to be members of a group and concern for the interests of the group. A Black American might be socially accepted while their Blackness is not. In that case, they are socially accepted qua person by not socially accepted qua Black person.

Consequently, this argument only applies to representatives of ideologies qua representatives of those ideologies. For ease of exposition, I'll take 'qua representative' as read and simply use the term 'representative' for most of the remainder of this paper, but please remember that it is specifically individuals in the guise of representatives that concern me.

9 If it is helpful, read my talk of intolerable ideologies as having no existential import. The thesis, then, would read: there is a negative, pro tanto moral obligation to not voluntarily enter into business relationships with representatives of intolerable ideologies, of which there might be none. 
Perhaps an example of this principle in effect will help. Imagine a representative of Nazi ideology. Perhaps they wear a shirt emblazoned with Nazi iconography across the front and, across the back, the words "We Want the Total War."10 For the sake of argument, imagine that for whatever reason, you come to see this individual wearing this shirt as a normal, if distasteful, part of your community, even as you recognize that they espouse and represent Nazi ideology. How might this contribute to the inclusion of Nazi ideology in the public discourse?

Prior to coming to think of this individual wearing this shirt as normal, you would have rejected out of hand any views that smacked of Nazism, for you are (or perhaps were) a right-thinking individual. The sight of a swastika at a campaign rally would have immediately made you deaf to the words of anyone standing on that platform. You would not deign to debate with a Nazi. But now? You still do not accept Nazi ideology. In fact, you remain vehemently opposed to it. But, whereas before you'd have seen such views as beneath contempt and deserving of no debate, you now feel that you must refute such views. After all, this is a view held by people in your community. You can't allow it to take root! But by debating the "issues," you've accepted the view into the public discourse, even if you reject the view itself. You've accepted that it is a position that can be held by someone in your community, even if they shouldn't hold it.

\section{(C1) There is a negative, pro tanto, moral obligation to not exercise political power in such a way that it grants social acceptance to representatives of intolerable ideologies (from P1, P2)}

From the above claims, there arises a pro tanto obligation against exercising political power to grant any degree of social acceptance to representatives of intolerable ideologies. Note that the same considerations would not generate an obligation against granting social acceptance to representatives of morally wrong ideologies simpliciter. A liberal society must permit the defense of falsehoods and wrongful practices, though it need not adopt those falsehoods or practices. While it might be permissible for individuals to

10 In answer to the question asked by Joseph Goebbels (1943). 
not grant social acceptance to representatives of morally wrong ideologies, I am not arguing that the mere fact that they are morally wrong generates an obligation to not grant social acceptance to their representatives. The above considerations only generate an obligation to avoid extending any degree of social acceptance to the representatives of intolerable ideologies qua representatives of ideologies that are beyond the pale.

\section{(P3) Entering into business relationships with a representative of an ideology (i) is an exercise of political power that (ii) grants social acceptance to that representative}

I take the preceding premises to be fairly uncontroversial. The most controversial claim of my argument is that extending the offer of business relationships is not a politically neutral activity. The primary support for this contention comes from the fact that business is a pillar of the community, that it is integral to the way we live our lives and the way we understand those around us. Business, as an institution, has a social cache that individuals lack. This accounts for both the political nature of business activity and the heightened power of that activity to lend social acceptance to individuals.

The power that businesses wield is political power. The employment of a known member of the $\mathrm{Ku}$ Klux Klan was once defended to me on the grounds that, whatever the man's personal failings, he was a good salesman and the relationship with him was "only business." Implicit in this is the claim that, while it might be unacceptable to associate with the salesman in one's private life, it is perfectly acceptable to do so in one's business life. I contend that, insofar as these obligations differ, they are more stringent, not less, in the latter.

No doubt, many businesses prefer to think of their decisions as private choices, choices that are not open to the same sort of moral criticism that is leveled at, say, the policy decisions of a politician. While the decision to include or exclude someone from a business relationship might not be quite so public as the decision to include or exclude someone from the political franchise, neither is it so private as the decision to include or exclude someone from a friendship. If we take seriously the contention that 
business is a pillar of the community, then we must accept that, to some extent, the commercial power of businesses is political and, thus, exercise of it is the exercise of political power.

First, business occupies a central role in the public life of the community. It is undeniable that a significant portion of our social lives occurs within the penumbra of economic activity. For better or worse, our work tends to define us and legitimate us to the community. Any number of socially undesirable traits can be forgiven in one with a steady job: "Jerry might be a stoner, but he gets to work on time every day and always hits his quotas." The small business owner occupies a near mythological place in our politics. "What do you do?" is shorthand for, "How are you employed?" Interactions that might have once occurred primarily in the purely private home or a purely public space now occur almost exclusively in an economic setting: "Let's catch up. Meet me at the coffee shop?" A credit check is a prerequisite for securing housing and is, thus, a prerequisite for being perceived as a full member of the community. In other words, inclusion in, or exclusion from, economic life has become tantamount to inclusion in, or exclusion from, the public life of the community. This inclusion, or exclusion, from the public sphere is necessarily political action. Therefore, exercising power to bring about that effect is an exercise of political power.

Second, commercial activity is not just permitted but facilitated by the exercise of political power, and that makes the power a business wields, to some extent, an extension of that political power. Societies with market economies have made various accommodations to ease the exercise of commercial power, e.g., the provision of limited liability, the public funding of infrastructure, tax incentives, etc. Markets themselves only exist within a framework of rules, which in turn are created through political processes for the benefit of society.

If activity were merely permitted or protected through the use of political power, that would not suggest that the activity in question is political. I have the right to free speech, and the state's protection of that right does not make all of my speech political. If, however, the state used its power to amplify my voice, my voice would then become political, at least insofar as that amplification makes it louder than 
the voices of others. Thus, the power that businesses have over and above that of private citizens is political power.

Were things otherwise, it might be that businesses would hold no special place in society and no special obligations. Perhaps they would be of moral interest only insofar as they raise questions of collective agency. But since businesses have been vested with various protections by society, protections that, far from being foisted on unwilling businesses, have made modern business possible, businesses cannot abdicate their political power, and attendant responsibilities, without likewise abdicating their commercial power. ${ }^{11}$

So far I've established that the power the businesses wield, at least insofar as it is greater than the power that individuals wield, is political power. Next, I must establish that accepting a representative of an ideology into a normal business relationship grants social acceptance to that ideology. The primary evidence for this claim comes from the social contact hypothesis, or the mere exposure effect, which holds that increased contact between members of two groups promotes social acceptance between those two groups (Allport 1954 and Pettigrew and Tropp 2008, 2011). This effect is stronger the less superficial the contact and the greater the group salience, i.e., the more relevant the membership in the group. Working side-by-side for long periods with someone who is a proud and vocal member of a group would be ideal circumstances for the contact effect to take place. While the greatest amount of research has been carried out on the contact effect between racial groups, studies have found that the hypothesis holds for a much wider range of groups, including those that are not marked by obvious outward differences (Bornstein 1989, Harmon-Jones and Allen 2001, Lee 2001, and Zajonc 1968). It is worth noting that research indicates the mechanism of that effect is affective, not cognitive. It is not increased knowledge

11 While my argument does not depend on any specific normative framework, Joseph Heath's (2014) market failures approach to business ethics seems particularly fitting. In that framework, the role that business plays in society determines the special obligations that businesses have. Since businesses serve the role of public forum, they have an obligation to police that forum, ensuring that those who should have access do and those who should not do not. 
of the group that does the work of increasing social acceptance. Rather, it is the decrease of anxiety around and the increase of empathy for the group that does the work (Pettigrew and Tropp 2008).

This suggests two things. First, when the contact is superficial or the representation not particularly obvious, the moral obligation is lessened since the likelihood of increased social acceptance is lessened. There is more reason to refuse to hire the mechanic with a swastika tattooed on his face than there is to refuse to sell groceries to the person wearing the t-shirt of an obscure white nationalist group. Second, we cannot count on critical reflection to prevent increased social acceptance. If the effect occurred through increased awareness of the views and features of the group, then social acceptance might be moderated by critical reflection on those views and features. But since the mechanism of the effect is affective, critical reflection is much less likely to occur.

The contact effect is why visibility of, and pride in, group membership are important tactics in movements fighting for the acceptance of their concerns into public discourse. When individuals who have already been granted social acceptance qua individual make undeniable their representation of a broader group or ideology, that forces a decision: reject the individual from membership in the community or take seriously their concerns qua representative. When you cannot ignore the fact that friends, coworkers, neighbors, teachers, and other members of your community are homosexual, you must either take seriously the possibility that homosexuality is not adequate grounds for discrimination, or you must reject those members of your community. ${ }^{12}$

Any degree of public acceptance of the representatives of an ideology or practice creates feedback pressure for greater degrees of acceptance. Consider the ability of same-sex partners to publicly display affection for one another. This ability not only expresses the normalization of same-sex romance, but also reinforces that normalization. If same-sex partners were never permitted to display affection 
publicly, if the social environment never permitted individuals to express their homosexuality openly, the pace of public acceptance of homosexuality would have been greatly slowed.

So, the social contact that occurs through ordinary business activity is likely to promote social acceptance. However, if it grants no more social acceptance than would be produced through private relationships, then this effect of ordinary business activity might not be an exercise of political power. And if it grants social acceptance to individuals qua individuals but not qua representatives, then it will not be an exercise of political power that grants social acceptance to a representative of an intolerable ideology qua representative. History bears out that both of these concerns are settled in favor of this argument.

Consider, for example, the way that economic exclusion has led to the construction and maintenance of the Otherness of Black Americans. A significant part of the fight for the social acceptance of Black Americans has occurred in the economic sphere: the fight for equal access to business loans, for access to the full range of consumer options, for an end to discrimination in hiring ${ }^{13}$ and promotion, for an end to the red-lining in the provision of mortgages. While a part of the fight is, no doubt, for access to the material benefits that full inclusion in the economic world provides, and a part of the fight is also for the recognition of the humanity of individual Black Americans, it is also clear that a part of the fight is for social acceptance of Black Americans as Black Americans.

So, because of the central role that business plays in our communities, because of the powers and privileges granted to business by society, when a business accepts or permits a representative of an intolerable ideology into an ordinary commercial relationship, they exercise political power in such a way that social acceptance is granted to that representative. These ancillary effects of ordinary business activity need not be intentional to exist. It is uncommon for those engaged in the day-to-day workings of

13 Cases of prejudicial exclusion clearly demonstrate an exception to the contention of Barry Maguire and Brookes Brown (2019) that market exchanges do not express the attitudes of one participant toward the other. I am here arguing for a further exception: against the background of a society where much of our daily activity occurs within an economic setting, granting someone entrance to that setting expresses an attitude of acceptability. 
the economy to think of the impact that their actions have vis-à-vis the inclusion or exclusion of individuals, communities, and ideas. Indeed, invisibility is precisely what we would expect from a process that is so deeply intertwined with our lives. Just as we give little thought to the inner workings of our vehicles until they malfunction, we give little thought to the political importance of inclusion in economic relationships until it is made conspicuous by its absence. Still, it is present in the normal, everyday functioning of the economy.

\section{(C2) There is a negative, pro tanto, moral obligation to not enter into business relationships with representatives of intolerable ideologies (from $\mathrm{C1}, \mathrm{P3}$ )}

If all of the above is right, then there exists an obligation to avoid entering into business relationships with representatives of intolerable ideologies. This obligation requires some further development, however.

First, note that the obligation is only pro tanto. Were there a situation where engaging in business relationships with such a representative would not contribute to the acceptance of that ideology into public discourse, the obligation would be overridden. Furthermore, the obligation might be outweighed by stronger obligations in favor of entering into business relationships with representatives of intolerable ideologies. For example, some have argued that discrimination against neo-Nazis serves to legitimize their pretense of innocent aggrievement, resulting in greater social acceptance than would be gained through acceptance into ordinary business relationships. If this were so, then the obligation to not enter into business relationships with neo-Nazis might well be overridden.

Second, as noted above, this obligation only applies to representatives of intolerable ideologies qua representatives. If Nate is a Nazi, but he is not currently wearing any regalia, nor marching in a proNazi demonstration, nor otherwise representing that ideology, then any refusal of social acceptance to Nate under those conditions would not be the refusal of social acceptance to Nate qua representative of a genocidal ideology and would not be justified by the argument above. In this way, Nate the Nazi would 
not have to starve due to the absence of a grocery store that will sell to him so long as he is willing to cover up his swastikas when he goes shopping.

This is not to say that it is clear just what it takes to actively represent an ideology. Would a haircut and a choice of clothing often associated with neo-Nazis be sufficient? Certainly the possibility of mistakes must be considered. The sociological complexities of the skinhead subculture are lost on most Americans: many would be surprised to learn of the existence of skinheads against racial prejudice, for example. This issue is discussed in objections below.

Furthermore, some people may be so intimately associated with an ideology that it would be impossible for them to not represent that ideology. David Duke's relationship to the Ku Klux Klan comes to mind. In such cases, the danger of unavoidable, serious privation is real. However, I think this is a virtue of the view, not a flaw: anyone so intimately connected as this with an intolerable ideology really ought to be well and truly ostracized until they are willing to publicly repudiate that ideology. Those intimately tied with an intolerable ideology cannot doff like a cap the justified opprobrium associated with that ideology.

Third, the obligation is a negative obligation. It is not an obligation to signal public disapproval of an ideology or an individual, though that may be a consequence. Nor is it an obligation to attend to society's ills. It is, rather, an obligation to avoid contributing to those ills. It is an obligation to refrain from granting social acceptance. This conclusion will, I think, be acceptable in principle even to those who believe that businesses bear no positive moral obligation to aid others or improve society. Even if you do not think that the relatively affluent have an obligation to prevent starvation, surely you'd agree that they have an obligation to not contribute to it. Similarly, even if you think it is not a business's place to keep intolerable ideologies out of public discourse, surely you'd agree that they have an obligation to avoid helping them get in. 


\section{§3 OBJECTIONS}

(O1) What is intolerable to me might not be intolerable to you. So, who decides?

(O2) This is a slippery slope. While we might start with ideologies that we all agree are intolerable, there is no principled place to stop before we arrive at legitimate conceptions of the good life.

Both of these objections assume that there is no principled way to distinguish between intolerable ideologies and tolerable ideologies and that, without such a principle, we should treat no ideologies as intolerable. This false equivalence is tiresome. There are hard cases, but there are easy cases, too. It may be that Antifa is wrong, but let's not pretend that there is no moral difference between them and those who call for the extermination of entire peoples. A Nazi in contemporary America is not just choosing an edgy lifestyle that may not be for everyone. A well-functioning, morally acceptable society does not take all kinds. Indeed, it cannot and should not take some kinds. Nazis are one such kind. The fact that some seem to be losing sight of this simple fact is one of the catalysts for this project.

Note, also, that I am not arguing that the negative obligation to refuse to engage in business with representatives of intolerable ideologies ought to be ensconced in law, let alone enforced. It should go without saying that not all moral principles ought to be enforced: you should not cheat on your spouse, but I also should not stop you from doing it (though I might try to talk you out of it). I am arguing here that businesses have a moral obligation, not that we ought to force businesses to live up to that obligation. $^{14}$

The conclusion of this argument does require us to draw substantive distinctions between ideologies. It calls for policies of discrimination and non-discrimination that go beyond the merely formal, i.e, that are concerned not just with whether or not discrimination occurs but also with the nature of the object of that discrimination. We will not all agree on where these substantive distinctions fall. Some might believe that homosexuality is intolerable and take this argument to require discrimination

14 For more on the relationship of this thesis to the law, see (O8) below. 
against homosexuals. They are wrong about this; it is our duty to convince them of that. Likewise, some might believe that Nazism is tolerable. They, too, are wrong.

(O3) Some people might be wearing Nazi regalia ironically, or as part of a play. Some things that are not related to the Nazis might be misinterpreted.

We do not have complete control over the meanings of the symbols we employ. "I would like a tea" does not mean that I would like a coffee just because I want or intend it to. The meaning of a symbol is determined by linguistic communities. To wear something ironically is to wear it knowing that it will have one meaning to most and another to those who understand your intentions. I am concerned about the meaning it has to most. My worry is that the social acceptance of intolerable ideologies occurs slowly and subconsciously, that it is an instance of creeping normalcy (Diamond 2005:425). Thus, the surface meaning of the symbol is what matters for my argument. If you wear Nazi symbols ironically, you still represent a genocidal ideology to the public, and that is the problem. ${ }^{15}$ Similar considerations apply to those wearing regalia as part of a play or some other innocent activity. Outside of the context in which the innocent meaning of the symbols is clear, they are dangerous and cause for discrimination.

Regarding misinterpretation, there are two possibilities: public misinterpretation and agential misinterpretation. If it is the public that misinterprets, then the considerations from the previous paragraph apply. If it is only the moral agent, e.g., the store manager, who misinterprets, then this is simply a case of a moral principle misapplied. If Tom is hugging Mary, but I think he's attacking her and move to stop him, that is no mark against the claim that we ought to come to the defense of others, though it may be a reason for me to be more cautious in my application of that principle.

(O4) (P1) assumes that people are unthinking dupes who can be non-rationally manipulated into accepting positions, practices, and ideologies.

Yes it does, at least to some extent. It is undeniable that we are susceptible to non-rational influence and we would do well to plan ahead to prevent that influence when it is untoward. I love my spouse, and I

15 The punks of England in the 1970s and some American punk or heavy metal acts of the 80s and 90s flirted with Nazi iconography. The fact that it was for fashion or art does little to mitigate the danger. The Dead Kennedys had the right of it. 
have every intention of never cheating on her. It would be exceptionally irrational for me to do so. Just the same, there are possible situations that I would do well to avoid because they carry with them an increased likelihood of infidelity. I'll not be going on a week-long bachelor party bender in Las Vegas with a wild friend, for example. We ought to hope that any given person is capable of retaining their disgust at calls for genocide, but we also ought to recognize that there are dark corners within us all, and vigilance is required to keep what lurks therein from calling the tune. After all, some people sometimes commit genocide. ${ }^{16}$

An illustration of this is provided by recent events. In 2011, only $30 \%$ of white evangelical Protestants agreed with the claim, "immoral personal behavior does not preclude public officials from carrying out their public or professional duties with honesty and integrity." This is clearly a moral conviction, and perhaps one that is close to the core identities of the respondents. However, in October of 2016, an astounding $72 \%$ of the same demographic agreed with the claim (Jones and Cox 2016). A common hypothesis for this shift takes as a catalyst the arrival of Donald Trump on the political scene. The claim is that even beliefs that are close to our core identity are susceptible to deformation due to motivated reasoning: the outsized effect that beliefs concerning short-to-medium-term self-interest have on seemingly (epistemically) unrelated views. In short, many white evangelical Protestants believed either that a Trump presidency would be particularly good for them or that a Clinton presidency would be particularly bad for them, and their moral convictions were modified as a result. ${ }^{17}$ No doubt, they did not alter these beliefs intentionally, but rather that this change was effected at a subconscious level. The stealthy nature of such effects only increases the danger.

Similarly, some young white males might, through their exposure to the rhetoric of 'white genocide,' find that their antecedent anti- or non-racist attitudes are shifting in a decidedly racist, white-

16 I will spare the reader the long and terrible list of genocides perpetrated throughout history. See Jonathan Glover (1999) and Samantha Power (2002) for that. But it is worth keeping in mind that "it can't happen here" is only true until it does.

17 Recent work by Matthew MacWilliams (2016) indicates that the determining factor here might not be veniality but rather fear of change and acceptance of authoritarianism. The effect on my argument is the same either way. 
nationalist, if not white-supremacist, direction (Alfano, Carter, and Cheong 2018 and Johnson 2018). I assert that people are dangerously susceptible to non-rational manipulation because they demonstrably are.

(O5) The reason businesses have an obligation to not discriminate against Black Americans is that doing so signals social disapproval, causes material harm, and businesses have a negative moral obligation to avoid doing those things. Thus, if businesses have an obligation to discriminate against representatives of intolerable ideologies, it must be because they have a positive obligation to signal social disapproval. ${ }^{18}$

The idea here is that what's wrong about wrongful discrimination is not that doing so fails to satisfy some positive moral obligation to lend social acceptance to people, but rather just that it is harmful in various ways, and businesses have a moral obligation to avoid causing that harm. If that's right, then were there an obligation to discriminate against someone, it would be an obligation to cause that same harm, which would be a positive moral obligation, not a negative moral obligation. Furthermore, it would suggest that there is a middle ground between signaling approval and signaling disapproval, a middle ground that ordinary business activity can occupy.

First, I agree that when a business discriminates against someone on the basis of group membership, it does signal social disapproval of that group. Furthermore, I think that if entering into a voluntary business relationship with someone signals social approval of that group, it does so to a lesser degree than discrimination signals social disapproval. Even if my conclusion is correct, the moral obligation I defend is much weaker than the moral obligation to not discriminate against those who do not warrant exclusion from the public sphere.

However, I have argued that there is no middle ground between signaling social disapproval and signaling social approval, at least in the case of entering into voluntary business relationships. It may be that businesses have no obligation to extend social acceptance to representatives of groups that should be socially accepted. It could be that such businesses only do wrong by the harm they cause to the

18 Thank you to Christopher McCammon for this comment. 
individual. But that does not mean that the effect I've argued for does not occur; that does not mean that engaging in ordinary market transactions with representatives of groups lends social acceptability to that group. Denying a moral obligation to bring about the effect I've argued for does not deny the effect itself. When we perceive someone doing normal things, we tend to view them as normal to some degree. Participating in economic life is normal and, so, when we see representatives of Nazi ideology participating in economic life, we tend to see them as normal. This is why seeing a Nazi looking at the expiration date on a gallon of milk is incongruous: it juxtaposes perfectly normal behavior with something abnormal. ${ }^{19}$

In a famous passage from his essay, "Looking Back at the Spanish War," George Orwell describes his experiences as a soldier:

We were in a ditch, but behind us were two hundred yards of flat ground with hardly enough cover for a rabbit. We were still trying to nerve ourselves to make a dash for it when there was an uproar and a blowing of whistles in the Fascist trench. Some of our aeroplanes were coming over. At this moment, a man presumably carrying a message to an officer, jumped out of the trench and ran along the top of the parapet in full view. He was half-dressed and was holding up his trousers with both hands as he ran. I refrained from shooting at him. It is true that I am a poor shot and unlikely to hit a running man at a hundred yards, and also that I was thinking chiefly about getting back to our trench while the Fascists had their attention fixed on the aeroplanes. Still, I did not shoot partly because of that detail about the trousers. I had come here to shoot at Fascists; but a man who is holding up his trousers isn't a Fascist, he is visibly a fellow-creature, similar to yourself, and you don't feel like shooting at him. (1970: 193-4)

Orwell's vision of his enemy engaged in an ordinary activity, holding up his pants, humanized him. It became much harder for Orwell to summon the nerve to fire on him. Orwell's assessment of the situation is understandable, but wrong. The man in question was holding up part of his Fascist uniform, running along the parapets of the Fascist line, on a military assignment. That man was a Fascist and was acting in the role of a Fascist. As I would put it, that was a man qua Fascist.

The point is not that Orwell should have overcome his discomfort, but rather that seeing neoNazis engaged in ordinary activities makes it difficult for us to see them qua neo-Nazis. It obscures the

19 See Richard Fausset (2017) and the ensuing controversy for an illustration of the power of this juxtaposition. 
fact that there stands a symbol of hate and a representative of genocide. Being party to such obfuscation is not just a failure to act against the spread of a repugnant ideology; it is acting in a way that helps to spread it.

(O6) (P1) and (P2) equivocate on "inclusion of ideologies into the public discourse." When that is taken to mean that the ideologies gain traction and acceptance, $(P 1)$ is clearly true but (P2) is false. When that is taken to mean that the ideologies are merely considered for debate, (P2) looks more plausible by (P1) is no longer clearly true.

The simple answer to this is that consideration of ideologies in debates increases the likelihood of those ideologies gaining traction. Consider the contrary: intolerable ideologies, when debated, will be recognized as such and rejected. If that were so, then the ideology would not be intolerable in a liberal society since, ex hypothesi, liberal societies have the means to prevent the spread of such views. Perhaps this position is correct, but if so then the objection is not that I'm equivocating but that I have made a false presupposition in accepting that there is such a thing as an intolerable ideology. See footnote 11 above for a suggestion on how you might think about the argument in such a case.

That being said, I think it is worth looking at the connection between debating an ideology and accepting that ideology. Consider the, perhaps over-used, concept of the Overton Window: the range of positions that are live political options. The mere acceptance of an ideology into public discourse does not mean that it falls within the Overton Window. But it does distort that Window, pulling it in the direction of that view. If Nazi ideology becomes a part of the public discourse, even an unacceptable part, that makes previously unacceptable positions less outré.

(O7) Even if (C2) is right, the pro tanto obligation to discriminate will always be outweighed by our obligation to respect humanity in others. Whatever else a Nazi might be, they are a human being deserving of the respect and dignity owed all human beings. It is a refusal to recognize this in them when we refuse to admit them into the economic life of a society, and this is unacceptable.

I must argue that there is a space between disrespecting the humanity in a representative of a genocidal ideology and admitting them into the public sphere. I think that can be established. The key is the guise under which the individual is being kept from the public sphere. They are not being kept out qua human, 
nor qua who they are in their personhood. I do not have an argument to support it, but it is my sincere hope that it is impossible for someone to be essentially a representative of a genocidal ideology. Even in the case of someone whose public persona is tightly linked with that ideology, it is possible for them to extricate their identity. Though it would be difficult, Dylan Roof could repudiate the unacceptable views he has so far endorsed.

However, I am forced to maintain that were it to turn out that it is somehow possible for someone to be essentially a representative of a genocidal ideology, then it would cease to be the case that disrespecting them is disrespecting a person. They have become the embodiment of an idea and, so, disrespect toward them is only disrespect toward that idea. Again, this is a limiting case that I hope is merely theoretical.

So, what of Orwell's fascist? Would Orwell have disrespected the humanity in him had he fired? I think that the answer is 'yes,' given the effect it had on Orwell. That is, Orwell could not help but see the fascist qua human and, so, would be shooting him qua human. I would go further: I do not think that it is possible to do bodily harm to someone qua representative of an idea. This is my answer to the question of whether one should punch Nazis: no, because violations of bodily integrity necessarily bring one's humanity to the fore. Similarly, if someone is brought unconscious and bleeding into the emergency room, wearing a large swastika on their shirt, it is impossible to turn them away without disrespecting their humanity. With the caveat discussed in the previous paragraph taken as read, the salient category of someone who is bleeding out is always 'human.'

\section{(O8) Isn't it illegal for businesses to discriminate?}

Speaking only of the U.S. context, the legal prohibitions on discrimination are quite limited. At the level of federal law, the most relevant legislation are titles II and VII of the Civil Rights Act of 1964. The first forbids discrimination on the part of 'public accommodations' towards customers who would use those facilities, forbidding, for example, motels from refusing to rent rooms on the basis of race. The second forbids discrimination against employees. For example, this prohibits a chain of clothing stores from 
refusing to hire employees from a particular religion. However, these protections cover only particular features: race, color, religion, sex (including sexual orientation and gender identity), national origin, and later, disability. Since Nazism doesn't fall into any of these categories, it is not illegal to discriminate against Nazis in the provision of goods or services nor is it illegal to discriminate against Nazis in hiring.

But problems remain. First, nothing I have said so far precludes a religious doctrine from being intolerable, and second, nothing precludes a further expansion of the Civil Rights Act or the implementation of laws at the state level covering ideological orientation, broadly construed. So, in such a circumstance, does this argument require businesses to break the law?

The first thing to note is that the inclusion of some feature among those protected by law is a clear indication that the public debate concerning that feature has come down decidedly against its being intolerable. While I maintain that it is possible for such debate to arrive at the wrong conclusion, this would provide strong evidence against the intolerability of that feature and should give any business pause. Second, the obligation to discriminate is pro tanto: it can be outweighed by other considerations. It is plausible to assume that there is an obligation against violating the legitimate laws of the land. I suspect that the countervailing obligation would outweigh the obligation to discriminate in most, if not all, cases. Third, in circumstances where the obligation against violating the legitimate laws of the land are insufficiently weighty, or where the laws themselves are illegitimate, this argument does call for civil disobedience. It is at least conceptually possible that an ideology could be so intolerable that law-breaking would be justified in order to avoid promoting it. I don't take this to be a mark against the view.

Beyond discrimination on the basis of particular features is the question of freedom of speech. Is discrimination against someone for representing an ideology an unjust violation of their freedom of speech? Do First Amendment protections for freedom of speech give businesses the right to discriminate on moral grounds? These questions are particularly relevant to issues concerning information gatekeeping (Metoyer-Duran 1993, Laidlaw 2008, Cerf 2011, and Taddeo 2015, 2019), in the case of the 
first question, and the right to freedom of conscience (Corvino, Anderson, and Girgis 2017, Dieterle 2008 and Arneson 2010), in the case of the second question.

The First Amendment protects one's ability to express one's views from government interference. So, taken strictly, the First Amendment is irrelevant to the current discussion, except as regards the business activities of government agencies. That being said, it is commonly held that while businesses have no legal obligation to respect civil liberties like the freedom of speech, they nonetheless have a moral obligation to do so. One need look no further than the difficult situation that social media companies find themselves in, trying to neither censor their users nor permit their users to hijack the platform for unacceptable purposes. Generally, these companies have been understandably hesitant to act as arbiters of truth or appropriateness, at least outside of situations where the content in question posed a clear and present danger to individuals, as in the case of child pornography or threats of violence.

The topic of debate most relevant to my own concerns the question of whether these companies, because of the role they occupy, have a moral obligation to prevent the harm that such malefactors pose. The mainstream position seems to be that they do indeed bear such obligations. However, these are generally framed as positive moral obligations (Cerf 2011, Taddeo and Floridi 2016, and Laidlaw 2008). While it is true that online service providers are uniquely situated to prevent various harms by facilitating and monitoring the flow of information, it is also true that these information gatekeepers lend an air of respectability and truth to any information they let through the gates. Because of this tacit certification, there is a stronger negative obligation for online service providers to discriminate that can be established with weaker premises on the basis of my argument.

Finally, how does the freedom of conscience bear on the permissibility of discrimination on moral grounds? Assume that businesses have a very robust right to freedom of conscience. Let's imagine that they have a right to discriminate against anyone whom they believe represents wrongful ideas, behavior, etc. This would, by itself, say very little about my argument. It is possible to have a right to do something that you should not do. The right is a protection against others stopping you from doing it; it is not a 
moral permission to do it. Far less would having such a right entail anything about whether or not such discrimination would be morally obligatory.

That being said, it does strike me that robust protections for freedom of conscience, like those provided by the Religious Restoration Act ${ }^{20}$ invites reflection and discussion on which sorts of things are tolerable and which intolerable. Insofar as it has that effect, and does not chill such debate with a you-have-your-views-I-have-mine attitude, I see it as friendly to the broader social project I am here suggesting. ${ }^{21}$

\section{$\S 4 \quad$ APPLICATIONS}

\section{(A1) Is there any way to actually put this into practice?}

There aren't many bars in my town, and while I've been working on this paper, a group of young men displaying Nazi iconography have begun turning up at my favorite watering hole on a regular basis. I will admit that my reaction to this is visceral. It ties my stomach in knots and sours the drink in my mouth.

The situation was tense. There had already been several violent altercations between the Nazis and other patrons of the bar. The management had not provided any guidelines for the employees, and different employees were applying different standards. Some were throwing out anyone involved in any

altercations. Some were throwing out those who accused the Nazis of being Nazis. Others were trying their best to ignore the whole thing. Clearly, the management had to take some kind of stance on the issue.

It isn't often that ethicists get the opportunity to field test their theories while they're in the making, so I began by delivering my argument, tailored to this specific case, via an online platform. The

20 I am in agreement with John Corvino, Ryan Anderson, and Sherif Girgis (2017) that there is no good reason to limit such a law to religious objections rather than moral objections more broadly.

21 Thank you to an anonymous referee for pushing me for a more thorough-going treatment of the legal implications of my view. 
reaction was immediate and intense. All of the confusions that I am so careful to warn against in this paper cropped up. Setting those aside, the most common objection to my suggestion was (O3), that I was misinterpreting the symbols. I assure you that this is not the case.

The second most common objection was something like this: by calling on a local business to institute a clear policy against serving those displaying Nazi symbols, I was acting in a way that is unacceptable in a liberal society. But this claim is clearly false, even incoherent. Consider: either I'm right that there are intolerable ideologies even in a liberal society or I am not. If I am right, then using reason to oppose the spread of such an ideology is not acting in a way that is unacceptable in a liberal society. If, on the other hand, I'm wrong and there is no ideology that is unacceptable in a liberal society, then the view that I espouse, and my attempt to enact it through reasoned persuasion, would likewise fail to be unacceptable.

This is obviously a meta-argument. It doesn't do anything to establish the truth of my conclusion. It merely justifies my attempt to convince the management of the bar, and you, of it. It is worth noting, however, that my later appeal to the management of the bar convinced them, and they have since instituted a rule against serving anyone displaying Nazi imagery. So that's nice.

\section{(A2) Does this only apply to small, personal businesses?}

As I've presented this argument, it may seem that it applies only to small businesses and their interactions with individuals. This is misleading. Assuming that we can make sense of the notion of intolerable ideologies at an international or intersocietal level, the argument equally well applies to multinational corporations (MNCs) that associate themselves with pariah regimes. This argument could be used to establish that MNCs ought to have divested from South Africa during apartheid. It could also be used to establish that MNCs ought to leave Syria while it is under the Assad regime. The global economic order wields great power and when MNCs agree to work with a regime, they use that power to grant the regime some level of acceptability on the world stage. That result should be avoided. 


\section{(A3) Does this mean we should be rude to people?}

The view defended in this paper seems to bear directly on recent questions concerning civility in political dialogue. Should we be civil in our political discourse with others, regardless of their views? I'd like to avoid descending into a terminological debate over 'civility.' Instead, I will reframe the question: should we treat others as though they have legitimate political views regardless of the content of those views? If this is the question, then my argument clearly commits me to saying 'no,' at least when 'we' refers to businesses. When the views are intolerable, we ought not to treat them as though they are legitimate. As noted above, this requires us to make substantive judgments about what views are and what views are not tolerable.

In June 2018, President Trump's White House Press Secretary, Sarah Huckabee Sanders, attempted to dine at a Lexington, Virginia restaurant. Sanders was told that the restaurant would not serve her because they were morally opposed to Sanders' actions. As the White House Press Secretary, Sanders is among the most recognizable defenders of the administration's policies. Given the timing, it is likely that the restaurant was responding to the administration's zero-tolerance immigration policy, which has resulted in the separation of thousands of children from their parents at the U.S.-Mexico border.

Did the restaurant do as they should? Is the zero-tolerance policy intolerable? Yes and yes. Those who defend the creation of concentration camps for children are defending an intolerable view. This is true despite a significant portion of the U.S. supporting the policy; morality is not determined by a show of hands. ${ }^{22}$ Avoiding a world in which a significant portion of the population support such policies is one of the goals of this project. We should not normalize such policies by granting their defenders the same kind of social recognition we give to others. ${ }^{23}$

22 The comments regarding social constructivism in $§ 1$ notwithstanding.

23 An earlier version of this paper was presented at the 2018 International Vincentian Business Ethics Conference and the History Department Colloquium at the University of North Alabama. Thanks to the organizers of those events and those in attendance for the helpful comments. I would also like to thank Albert Casullo, Matt Fitzsimmons, Landon Hedrick, Katie Loughrist, Sruthi Rothenfluch, Steve Swartzer, Adam Thompson, and two anonymous referees for their invaluable feedback. 


\section{WORKS CITED}

Alfano, Mark and J. Adam Carter and Marc Cheong. 2018. "Technological Seduction and SelfRadicalization.” Journal of the American Philosophical Association 4: 298-322.

Allport, Gordon. 1954. The Nature of Prejudice. Cambridge, MA: Addison-Wesley.

Areneson, Richard J. 2010. “Against Freedom of Conscience.” San Diego Law Review 47:1015-40.

Bornstein, Robert. 1989. "Exposure and affect: Overview and meta-analysis of research, 1968-1987." Psychological Bulletin 106(2): 265-89.

Cerf, Vinton G. 2010. “First Do No Harm.” Philosophy of Technology 24: 463-5.

Corvino, John, Ryant T. Anderson, and Sherif Girgis. 2017. Debating Religious Liberty and Discrimination. New York: Oxford University Press.

Diamond, Jared. 2005. Collapse: How Societies Choose to Fail. New York: Viking.

Dieterle, J.M. 2008. "Freedom of Conscience, Employee Prerogatives, and Consumer Choice: Veal, Birth Control, and Tanning Beds.” Journal of Business Ethics 77: 191-203.

Fausset, Richard. 2017. “A Voice of Hatred in America's Heartland.” The New York Times, November 25, 2017. https://www.nytimes.com/2017/11/25/us/ohio-hovater-white-nationalist.html

Glover, Jonathan. 1999. Humanity: A Moral History of the Twentieth Century. New Haven: Yale Nota Bene.

Goebbels, Joseph. 1943. "Nation, Rise Up, and Let the Storm Break Loose." Speech delivered at the Berlin Sportpalast, February 18, 1943. https://research.calvin.edu/german-propaganda-archive /goeb36.htm

Harmon-Jones, Eddie and John J.B. Allen. 2001. "The Role of Affect in the Mere Exposure Effect: Evidence from Psychophysiological and Individual Differences Approaches.” Personality and Social Psychology Bulletin 27(7): 889-98.

Heath, Joseph. 2014. Morality, Competition, and the Firm: The Market Failures Approach to 
Business Ethics. New York: Oxford University Press.

Herek, Gregory and Eric Glunt. 1993. "Interpersonal contact and heterosexuals' attitudes toward gay men: Results from a national survey". Journal of Sex Research 30 (3): 239-244.

Johnson, Jessica. 2018. “The Self-Radicalization of White Men: 'Fake News' and the Affective Networking of Paranoia.” Communication, Culture and Critique 11: 100-15.

Jones, Robert, and Daniel Cox. 2016. “Clinton maintains double-digit lead (51\% vs. 36\%) over Trump.” Accessed May 3, 2018. PRRI. http://www.prri.org/research/prri-brookings-oct-19- pollpolitics-election-clinton-double-digit-lead-trump/.

Laidlaw, Emily B. 2008. "Private Power, Public Interest: An Examination of Search Engine Accountability." Journal of Law and Information Technology 17(1): 113-45.

Lee, Angela. 2001. "The Mere Exposure Effect: An Uncertainty Reduction Explanation Revisited." Personality and Social Psychology Bulletin 27(10): 1255-66.

MacWilliams, Matthew. 2016. "Who Decides When the Party Doesn't? Authoritarian Voters and the Rise of Donald Trump.” PS: Political Science \& Politics 49: 716-21.

Maguire, Barry and Brookes Brown. 2019. "Markets, Interpersonal Practices, and Signal Distortion." Philosophers' Imprint 19(14).

Metoyer-Duran, Cheryl. 1993. "Information Gatekeepers.” Annual Review of Information Science and Technology 28: 111-50.

Mill, J.S. 1859. On Liberty. London: John W. Parker and Son.

Nyhan, Brendan and Jason Reifler. 2010. "When Corrections Fail: The Persistence of Political Misperceptions.” Political Behavior 2: 303-30.

Orwell, George. 1970. “Looking Back on the Spanish War.” In A Collection of Essays ed. George Orwell. New York, NY: Mariner Books.

Pettigrew, Thomas and Linda Tropp. 2008. "How Does Intergroup Contact Reduce Prejudice? Metaanalytic Tests of Three Mediators.” European Journal of Social Psychology 38: 922-34. 
. 2011. When Groups Meet: The Dynamics of Intergroup Contact. New York: Psychology Press.

Popper, Karl. 1945. The Open Society and Its Enemies. London: Routledge.

Power, Samantha. 2002. A Problem from Hell: America and the Age of Genocide. New York: Basic Books.

Rawls, John. 1971. A Theory of Justice. Cambridge, MA: Belknap Press. . 2005. Political Liberalism. 2nd ed. New York: Columbia University Press.

Reich, Robert. 2015. Saving Capitalism: For the Many, Not the Few. New York: Knopf.

Sandel, Michael. 1996. Democracy's Discontents: America in Search of a Public Philosophy. Cambridge, MA: Belknap Press.

Taddeo, Mariarosaria. 2015. "The Struggle Between Liberties and Authorities in the Information Age." Science and Engineering Ethics 21: 1125-38. . 2019. “The Civic Role of Online Service Providers." Minds and Machines 29: 1-7.

Zajonc, Robert. 1968. “Attitudinal Effects of Mere Exposure.” Journal of Personality and Social Psychology 9(2): 1-27. 